\title{
Nominee Agreements in the Sale and Purchase of Proprietary Land by Foreign Citizens (Analysis of the Supreme Court Decision Number 50PK / PDT / 2016)
}

\author{
Titi Maesarah Putri Salim H S Djumardin \\ Notary Master Study Program, Faculty of Law, University of Mataram, Indonesia
}

\begin{abstract}
This study examines the legal power of nominee agreements and the basis of judge consideration in deciding and adjudicating cases related to nominee agreements. The research method used is normative legal research method. The approach used is a statutory approach, a conceptual approach and a case approach. The results of the study obtained that, the first is that the nominee agreement has no legal force because it does not meet the validity of an agreement contained in Article 1320 of the Civil Code (KUHPerdata) and break the Article 1335 and Article 1337 of the Civil Code (KUHPerdata). Second, the panel of judges decides and adjudicates the case is not in accordance with the principle of legal certainty because the judge does not provide a basis for consideration in accordance with the applicable law, namely the UUPA. The panel of judges acknowledged and confirmed that the nominee agreement was made between the husband of the Petitioner for Reconsideration and the Respondent for Reconsideration, so that in this decision the judge won the Petitioner for Reconsideration who was a foreign citizen.
\end{abstract}

Keywords: Nominee Agreement, Foreign Citizen, Land Rights Control.

DOI: $10.7176 / \mathrm{JLPG} / 112-09$

Publication date:August $31^{\text {st }} 2021$

\section{INTRODUCTION}

Law Number 5 of 1960 concerning Basic Agrarian Principles, State Gazette of the Republic of Indonesia of 1960 Number 104, Supplement to the State Gazette of the Republic of Indonesia Number 2043 or what is known as the Basic Agrarian Law (hereinafter abbreviated as UUPA) is a reference in Indonesian Land Law. According to Arba (2017) UUPA contains several principles,namely the principle of nationality and the principle that only Indonesian citizens can have ownership rights over land. The principle of the principle of nationality, the entire territory of Indonesia is the unity of the homeland of all Indonesian people who are united as the Indonesian nation. This shows that the land for the Indonesian people has a communalistic character, meaning that all land in the territory of the Republic of Indonesia is the common land of the Indonesian people who are united as the Indonesian nation (Santoso, 2015:6).

The UUPA states that articles regulating legal subjects who can be granted and have land rights, namely Article 21 paragraph (1) of the UUPA, only Indonesian citizens can have property rights. This provision determines that an individual who is only Indonesian citizen can have property rights. In addition, there is Article 21 paragraph (2) UUPA, which states that the government determines legal entities that can have property rights and the conditions thereof.

Furthermore, in the national land law also has the principle that only Indonesian citizens can have property rights to land, this principle confirms that only Indonesian citizens who are domiciled as the subject of property rights. People of foreign nationality domiciled in Indonesia cannot own land that is property status, but only have land that is united in usage rights and rental rights (Santoso, 2015:8). Even people who are both Indonesian citizens and foreigners cannot have ownership rights over land.

Article 26 paragraph (2) UUPA regulates actions that foreign nationals who get ownership rights then the land is controlled by the state. The article, namely:

"Any sale, exchange, granting, giving by will and other acts intended to directly or indirectly transfer property rights to a foreigner, to a citizen in addition to his/her Indonesian citizenship has a foreign nationality or to a legal entity, except as stipulated by the Government referred to in Article 21 paragraph (2), is null and void because the law and the land fall to the State, provided that the rights of the other party who burden it continue and that all payments received by the owner cannot be reclaimed".

Although only Indonesian citizens are allowed to own land with the status of property rights, not a few foreign citizens have the desire to control land with the status of property rights. There are many ways to achieve this goal, one of which is by making a nominee agreement. The nominee agreement is an effort to allow foreign citizens to own land in Indonesia.

In response, Maria SW Sumardjono argued that "by using "guise", doing a trade on behalf of 
an Indonesian citizen, so that formal juridically does not violate the rules. But in addition, efforts were made to make agreements between indonesians and foreigners by means of power (often referred to as absolute power), which gives irrevocable rights by the absolute authority (WNI) and gives authority for the beneficiary (WNA) to perform all legal acts with respect to the right to the land, which according to the law can only be done by the rights holder (WNI) so that in essence it is the transfer of land rights" (Sumardjono, 2007:166).

Nominee agreements are agreements that are often made between foreign nationals and Indonesian citizens, whereby an Indonesian citizen lends his name to a foreign national with the intention that foreign nationals can own land in Indonesia. few parties to the nominee agreement ultimately dispute. Disputes between the two parties in practice can be resolved with the result of the land dispute falling to or controlled by either party. Article 26 paragraph (2) of the Constitution clearly mentions the consequences of actions that directly or indirectly to transfer land to foreign nationals, then the land belongs to the state.

In an agreement must meet the terms of the validity of the agreement, namely the word agreement, proficiency, certain things and a lawful cause, as specified in Article 1320 of the Civil Code. With the fulfillment of the four terms of the validity of this agreement, an agreement becomes valid and legally binding for the parties making it (Suharnoko, 2015:1).

An example of a case related to the nominee agreement is contained in the Supreme Court Decision No. 50PK/Pdt/2016 in which a foreign national, Namely Mrs. Susi Johnston against an Indonesian citizen namely Tety Carolina and a Notary I Made Pria Dharsana. Land disputes in question in the case in the form of property rights, namely:

1. Property Rights No. 1860/ Buduk Village, covering an area of $665 \mathrm{~m}^{2}$, Measuring Letter dated May 13, 1998, Number 13/1998 obtained on the basis of buying and selling with Mr. Andrianto Kariadi based on the Deed of Sale and Purchase Dated 14-1-2000 with Number 3/2000 made before Notary / PPAT Tutik Danakusuma, S.H.;

2. Property Rights No. 1861 / Buduk Village, covering an area of $298 \mathrm{~m}^{2}$, Measuring Letter dated May 13, 1998, Number 15/1998 obtained on the basis of buying and selling with Mr. Andrianto Kariadi based on the Deed of Sale and Purchase dated 14-1-2000 with Number 2/2000 made in Notary / PPAT Tutik Danakusuma, S.H.;

3. Property Rights No. 1319 / Buduk Village, covering an area of $1,650 \mathrm{~m}^{2}$, Situation Picture dated February 7, 1996, Number 834/1996 obtained on the basis of buying and selling with Mr. Andrianto Kariadi based on the Deed of Sale and Purchase Date 14-1-2000 with Number 1/2000 made in Notary / PPAT Tutik Danakusuma, S.H.

The three property rights were obtained on the basis of an agreement dated January 24, 2000 with the legalization of Number 3258L/2000, by Tutik Danakusuma, S.H., Notary in Denpasar, Bali. The agreement proves that the existence of the name Tety Carolina (Respondent PK I) listed in SHM No. 1860 / Buduk Village, Number 1861 / Buduk Village, and Number 1319 / Buduk Village is only limited by just borrowing names, and not as the owner.

The case is one of many examples of cases occurring in the community regarding name loan agreements made by foreign nationals with Indonesian citizens.

Normative legal research in this writing has a norm vacuum because there are no specific rules governing nominee agreements, so that judges in deciding judicial disputes are different. For example, in the Decision of the Supreme Court Number 50PK / Pdt / 2016, which the author will examine, there are judges who acknowledge the nominee agreement made by the parties, namely between foreign nationals and Indonesian citizens. So that in the verdict the judge won the foreign citizen and the property rights fell to the foreign citizen.

The legal problem, namely how the legal force of the nominee agreement itself is and what is the basis for judges' considerations in hearing and deciding cases related to the nominee agreement. Thus the purpose of this study is to explain and analyze the legal power of nominee agreements in the sale and purchase of property rights by foreign citizens and to explain and analyze the basis for consideration of Supreme Court judges in hearing and deciding cases related to the nominee agreement.

\section{RESEARCH METHOD}

The research method used in this research is normative legal research. The approach used in this research is using a statutory approach, conceptual approach, case approach and analytical approach. Types and sources of research data using primary, secondary and tertiary data. The data collection technique is using literature study. The data analysis in this study carried out by qualitative data analysis and the conclution of this study use the deductive method. 


\section{FINDING AND DISCUSSION}

\section{A. LEGAL FORCE OF NOMINEE AGREEMENT IN THE SALE AND PURCHASE OF PROPERTY} BY FOREIGN NATIONALS

According to Maria S.W Sumardjono $(2001 ; 140$.) One of the characteristics of property rights is that they can become mains of other land rights, for example, Building Use Rights (HGB), Lease Rights for Buildings, and Use Rights. The UUPA stipulates that only Indonesian citizens can become the subject of property rights as in Article 9 jo Article 21 of the UUPA (Sumardjono, 2001;140).

Furthermore, strictly speaking, foreign citizens cannot become the subject of property rights as in Article 26 paragraph (2) of the UUPA. However, there are many ways that foreign citizens have to own land with the status of ownership rights. Many violations were committed by both foreign nationals and Indonesian citizens in terms of land tenure, as mentioned above.

The practice of land tenure that is most often carried out in the community is by entering into a nominee agreement or a name loan agreement between a foreign citizen as the borrowing party and an Indonesian citizen as the party whose name is borrowed. One example of a case related to a nominee agreement occurred in Bali, as in the Decision of the Supreme Court Number 50PK / PDT / 2016, namely the underhanded nominee agreement was made which was legalized by Notary Tutik Dana Kusuma, S.H., M.Kn. among the citizens of Italy, namely Mr. Bruno Piazza (deceased) with an Indonesian citizen (Tetty Carolina) to control the freehold land. Then the land becomes disputed land at a later date with the disputing parties, namely the heirs of Mr. Bruno Piazza (deceased) who in this case was his legal wife, namely Susan Elizabeth Johnston against Tetty Carolina and I Made Pria Dharsana (Notary).

The nominee agreement is the basis for further legal action, namely the purchase of three parcels of freehold land, including:

1. Property Rights Number 1860 / Village Buduk, covering an area of $665 \mathrm{~m}^{2}$, Measurement Letter dated May 13, 1998, Number 13/1998 obtained on the basis of a sale and purchase with Mr. Andrianto Kariadi based on the Sale and Purchase Deed dated 14-1-2000 with Number 3/2000 which made in the presence of a Notary / PPAT Tutik Danakusuma, SH;

2. Property Rights Number 1861 / Village Buduk, covering an area of $298 \mathrm{~m}^{2}$, Measurement Letter dated May 13, 1998, Number 15/1998 obtained on the basis of a sale and purchase with Mr. Andrianto Kariadi based on the Sale and Purchase Deed dated 14-1-2000 with Number 2/2000 which made at Notary / PPAT Tutik Danakusuma, SH;

3. Property Rights Number 1319 / Village Buduk, covering an area of $1,650 \mathrm{~m}^{2}$, Situation Picture dated February 7, 1996, Number 834/1996 obtained on the basis of a sale and purchase with Mr. Andrianto Kariadi based on the Sale and Purchase Deed dated 14-1-2000 with Number 1/2000 which made at Notary / PPAT Tutik Danakusuma, SH.

The three property rights were obtained on the basis of an agreement dated January 24, 2000 with legalization Number 3258L / 2000, by Tutik Danakusuma, S.H., Notary in Denpasar, Bali. The agreement proves that the existence of the name Tety Carolina (PK I Respondent) listed in SHM Number 1860 / Village Buduk, Number 1861 / Village Buduk, and Number 1319 / Village Buduk is only limited to borrowing names, and not as the owner.

In the Supreme Court Decision No. 50PK/PDT/2016 p. 27, in one of the considerations the judge mentioned:

"Whereas the Petitioner for Reconsideration is the legal wife of Bruno Piazza who has borrowed the name of Tety Carolina (Respondent for Reconsideration) to buy three plots of land with title certificates accompanied by an agreement dated January 24, 2000 in the presence of Notary Tutik Danakusuma"

"Whereas the Respondent for Reconsideration has only borrowed his name so that the three certificates of ownership in the name of the Respondent for Reconsideration are not accompanied by original evidence and the obvious mistake is that until now there has been no sale and purchase deed, only a sale and purchase agreement so that there has been no transfer of property rights".

Based on the judges' opinions above, the judge indirectly acknowledges the nominee agreement made by the parties. In this thesis, the author will analyze how the legal force of the nominee agreement itself is so that the judge in his consideration acknowledges the nominee agreement and wins foreign citizens.

If seen from the terms of the validity of an agreement contained in Article 1320 of the Civil Code (KUHPerdata), the nominee agreement is null and void.

1. Agree those who bind themselves.

A deal is an absolute condition of an agreement, in which both parties to an agreement must agree or agree on the subject matter of the agreement. If the word agrees there is no one among them will make an agreement then there is no agreement.

2. Competent to make an agreement.

Article 1329 of the KUHP states that everyone is capable of making an agreement, unless according to law 
it is declared incompetent. Article 1330 of the Civil Code determines who is not competent to enter into an agreement. These incompetent people, namely minors, those who are placed under interdiction, women who are married in matters stipulated by law, and generally all persons who are prohibited by law from entering into certain agreements.

3. Regarding a certain matter.

An agreement must have a certain object. This object is what is meant by a certain thing in the terms of the validity of the agreement. When the law talks about the object of the agreement, sometimes what is meant is the subject of the engagement and sometimes it is interpreted as the point of achievement. Article 1234 of the Civil Code, the main achievement can be in the form of giving something, doing something, or not doing something. A particular matter referred to in Article 1320 of the Civil Code is the debtor's obligation and the debtor's right. This means that certain matters are what was agreed upon, namely the rights and obligations of both parties (Suherman \& Satrio, 2010;186).

4. A lawful (halal) reason.

Halal here means that existing legal causes do not conflict with statutory regulations, public order, or morality. Article 1335 Jo 1337 of the Civil Code states that a cause is declared prohibited if it is contrary to law, decency, or public order. A cause is declared contrary to law if the cause in the agreement in question is contrary to the applicable law. The term decency has different meanings in each group of society, besides that people's assessment of someone is different, so that a cause is said to violate decency is not easily determined. It is up to the judge to determine whether or not a cause violates decency is up to the judge, where the judge must seek views of the values that live and develop in the community concerned. A cause that violates public order, namely matters relating to public interests, state security, and unrest in society as well as unrest in the state administration (Khairandy,2014).

The first and second requirements are subjective requirements because they must be fulfilled by legal subjects. While the third and fourth conditions are objective conditions, where these conditions must be met by the object of the agreement. Failure to fulfill the subjective conditions results in an agreement can be canceled, while if the conditions of the object are not fulfilled it will result in a null and void agreement, which means that the agreement from the beginning is deemed never to exist. As a result of the cancellation, whether it is null and void or after a claim for cancellation has the same legal consequences, that is, it has no legal consequences (Budiono, 2010;381).

The nominee agreement does not meet any of the objective requirements, which is the fourth condition. Halal kausa means that the kausa is not contrary to law, decency, and public order. The nominee agreement which in this case is intended to own property by foreign nationals means that it has violated the law, namely UUPA. The provisions in the Law violated are Article 9, Article 21 and Article 26 paragraph (2).

Article 1335 of the Civil Code states, "an agreement without cause, or which has been made due to false or prohibited causes, has no power." Then Article 1337 of the Civil Code states, "a cause is prohibited, if it is prohibited by law, or if it is prohibited by law, or if it is contrary to decency or public order."

In this case the nominee agreement clearly violates the law, namely the UUPA and is made to carry out legal smuggling, because the nominee agreement is made between foreign citizens and Indonesian citizens to cheat the law because basically the UUPA prohibits foreign citizens from owning land with rights status. ownership. In addition, the nominee agreement was made on the basis of a false reason because the nominee agreement was made under the pretense, namely Indonesian citizens pretending to be the party who owns the land that is right of ownership even though in fact the owner of the land is a foreign citizen, all costs to own the land comes from the party of a foreign citizen, so that in this case the Indonesian citizen is only the party whose name has been borrowed. If you look at the sound of Article 1335 and Article 1337 of the Civil Code, it is clear that the nominee agreement violates the law and contains false reasons, then the agreement results in no power.

If seen from the sound of Article 26 paragraph (2) UUPA:

"Any sale, exchange, granting, giving by will and other acts intended to directly or indirectly transfer property rights to a foreigner, to a citizen in addition to his/her Indonesian citizenship has a foreign nationality or to a legal entity, except as stipulated by the Government referred to in Article 21 paragraph (2), is null and void because the law and the land fall to the State, provided that the rights of the other party who burden it continue and that all payments received by the owner cannot be reclaimed".

If the article is seen, the nominee agreement is an act that indirectly transfers property rights to foreign nationals, then the nominee's agreement is null and void because the law and land that is the object of the agreement belongs to the state.

However, materially there is a will that is not in accordance with the statement. In other words, if someone consciously proposes a legal action that is not in accordance with the reality then a simulation occurs. An agreement that regulates everything that is different from the actual situation for a particular purpose is known as a simulation which comes from the word simulation, simulated contract, ostensible action (UK); schijnhandeling 
(Netherlands); simulatio (Latin).

One of the causes of the discrepancy between will and statement is because the parties do not want the legal consequences of what they state. This is then poured into a simulated agreement. It can be said that between the parties there has been a conspiracy to secretly and knowingly commit a legal action that deviates from what should have happened (Budiono, 2010;86).

In order to be said to have occurred a simulation or a mock legal act, there is a need for deviations between wills and statements that give the impression that it has occurred a certain agreement. But in secret the parties made a second agreement stating that there was no legal result of their previous legal actions (Budiono, 2010;87.).

Parameters for determining an agreement, including a simulated agreement or mock agreement, are based on statutory regulations or legal principles as a coherent truth criterion, namely: 1 . Article 1873 of the Civil Code which states that: "Further approval, which is made in a separate deed (which is contradictory to with the original deed, it only provides evidence between the parties, the heirs or right recipients, but cannot apply to third parties who have good intentions 2. Article 1320 of the Civil Code states that for the validity of an agreement, 4 conditions must be fulfilled including the conditions for existence. lawful causes. The law does not explain what is meant by lawful causes and only elaborates further in Articles 1335 and 1337 of the KUHP.

Thus, the nominee agreement creates legal uncertainty, because normatively the nominee agreement is null and void. These agreements are still recognized before the law, but there are difficulties in terms of proof in court because most of the agreements are made by notarial deeds so that they become perfect evidence. In the civil court system, judges see formal truth rather than material truth. Even though the judge has the belief that the series of agreements is a simulation agreement or nominee agreement, the judge cannot immediately cancel the agreement unless it can be proven that there is a prohibited cause in the agreement.

\section{B. THE BASIS OF THE JUDGE'S CONSIDERATION IN ADJUDICATING AND DECIDING CASES RELATED TO THE NOMINEE AGREEMENT}

\section{Position Case}

Mrs. Susan Elizabeth Johnston / Petitioner for Reconsideration, is an American citizen who lives together with Bruno Piazza, an Italian citizen, who together lived in Indonesia since 1995 and formally became the legal wife of Bruno Piazza since July 21, 2011 (according to Quote Marriage Certificate dated July 21, 2011), which later after Bruno Piazza passed away on October 28, 2011 in accordance with the Death Deed Number 759/2011, November 1, 2011, and therefore was the sole heir of Bruno Piazza, based on the Statement of Inheritance from / legalized by the Italian competent authority, on January 12, 2012.

In 1999 Bruno Piazza wanted to buy 3 three plots of land located in Buduk Village, Mengwi District, Badung Regency, Bali Province, as stated in the Freehold Certificate Number 1319 / Village Buduk, covering an area of 1,650 $\mathrm{m}^{2}$, Certificate of Ownership Number 1860 / Village Buduk, an area of $665 \mathrm{~m}^{2}$, and a Certificate of Ownership Number 1861 / Village Buduk, covering an area of $298 \mathrm{~m}^{2}$ which is located adjacent to each other and bordering (hereinafter referred to as the object of the dispute), from a local resident, namely Andriato Kariadi. With the advice / suggestions of Legal Counsels and Notaries / Land Deed Making Officials, due to constraints in the laws and regulations, a Sale and Purchase Agreement has been carried out with a Sale and Purchase Deed (AJB) Number 1/2000, 2/2000 and Number 3/2000 all of which are dated 14 January 2000 in front of Tutik Danakusuma, SH, PPAT in Denpasar (Bali) by borrowing / using the name Tety Carolina.

To ensure the interests of Bruno Piazza, an Agreement was made on January 24, 2000 between Bruno Piazza and Tety Carolina (Respondent PK-I) on the loan agreement of the name in question, which has been ratified by the same Notary-Official/PPAT, namely Tutik Danakusuma, S.H., Notary/PPAT in Denpasar, Bali with legalization No. 3258-L/2000.

The purchase of land and all costs of residential construction along with everything attached or standing on all three areas of land the object of dispute is entirely at the expense of Bruno Piazza (husband/Heir to the Review Applicant).

Then Respondent PK denied the binding agreement and he claimed to have made a lease agreement between Mr. Bruno Piazza, so that respondent PK I filed a lawsuit against applicant PK and Respondent PK as Notary. The respondent pk stated that he was the rightful owner of the three areas of land dispute.

\section{Regarding Judges' Legal Considerations}

Considering whereas against the reasons for the reconsideration, the Supreme Court is of the opinion:

Whereas the Petitioner for Reconsideration is the legal wife of Bruno Piazza who has borrowed the name of Tety Carolina (Respondent for Reconsideration) to buy three land parcels with title certificates accompanied by an agreement dated January 24, 2000 in the presence of Notary Tutik Danakusuma;

Whereas the Respondent for Reconsideration has only borrowed his name so that the three certificates of ownership in the name of the Respondent for Reconsideration are not accompanied by original evidence and the obvious mistake is that until now there has been no sale and purchase deed, only a sale and purchase agreement so that there has been no transfer of property rights; 
Whereas the Petitioner for Reconsideration did not attend the trial because the Respondent for Reconsideration had a bad faith because he was suing the Petitioner for Reconsideration by using the wrong address and name listed in the lawsuit. Defendant II is Susi Johnston who lives at Jalan Subak Pangi Number 9, Parerenan Village, Badung Regency, while the name of the Reconsideration Petitioner is Susan Elizabeth Johnston who lives at Jalan Sempol Number 20 Parerenan Mengwi, so that the Reconsideration Petitioner was disadvantaged because he could not defend his rights. his rights in court proceedings; Considering that there is a ruse from the Plaintiff so as not to include in his lawsuit the name of defendant II is actual or the actual address of Defendant II in the plaintiff's lawsuit while the Plaintiff has known about the name and address because Defendant II who holds / stores the certificate of original property on behalf of the Plaintiff has resulted in the Defendant losing the opportunity to defend his rights in the court proceedingsthen the lawsuit is a lawsuit that is imperfect so that it must be declared unacceptable;

Considering, whereas based on the above considerations, the Supreme Court is of the opinion that there is sufficient reason to grant the petition for reconsideration from Mrs. SUSI JOHNSTON and cancel the Supreme Court Decision Number 1540 K / PDT / 2014 dated 27 November 2014 and the Supreme Court will try this case again with a ruling as will be mentioned below;

Considering, that because the Respondent for Reconsideration / Cassation Respondent / Plaintiff / Appeal was on the losing side, he was punished to pay court fees at all levels of trial; Taking into account Law Number 48 of 2009 concerning Judicial Power, Law Number 14 of 1985 concerning the Supreme Court as amended and supplemented by Law Number 5 of 2004 and the second amendment to Law Number 3 of 2009 and statutory regulations -Other laws concerned.

\section{Judge's Decision}

Judge:

1. Granted the request for reconsideration from Mrs. The SUSI JOHNSTON;

2. Canceling the Decision of the Supreme Court Number 1540 K / PT / 2014 dated 27 November 2014.

\section{Re-adjudicating:}

In Exceptions:

- Refusing Defendant I exception entirely;

In the Main Case:

- Declare that the Plaintiff's claim is unacceptable;

In Conventions and Reconventions :

To punish the Respondent for Reconsideration, the Cassation / Plaintiff / Appeal Respondent to pay the court fee in this review examination in the amount of Rp. 2,500,000.00 (two million five hundred thousand rupiah).

Analysis of the Decision of the Supreme Court Number: 50PK / PDT / 2016 related to the Nominee Agreement

In fact, the court as a symbol of justice in its rulings always contains the content that the court will provide justice to every citizen, especially for justice seekers. Understanding and mastery of the roles, duties, and functions and obligations of judges in carrying out their duties and obligations professionally will allow to produce a judge's decision containing elements of justice, usefulness, and legal certainty. According to Margono, $(2019 ; 2)$ Such a judge's decision will reflect the sense of justice of the community if it is in accordance with the noble values contained in the Pancasila principles as a manifestation and implementation in exercising independent judicial power in order to uphold law and justice.

Judges have a role as law enforcers as well as in concreto lawmakers (Margono (2019; 9). The role of judges as lawmakers is always attached to every judge's decision which mutais mutandis contains casuistic law. In this case every judge tries seriously Indeed, through its decision it provides a new condition, either by creating a new legal rule that did not yet exist or by leaving or setting aside existing legal rules.

Judges in deciding a case, casuistically, are always faced with three principles, namely the principle of legal certainty, the principle of justice and the principle of expediency. As according to Sudikno Mertokusumo \& Pitlo (1993), the three principles must be compromised, namely by applying them in a balanced or proportional manner. In judicial practice, it is very difficult for a judge to accommodate the three principles in a single decision. In facing this situation, the judge must choose one of the three principles to decide a case and it is impossible for the three principles to be covered at once in a single decision.

When a judge makes a decision that is closer to the principle of legal certainty, the judge will automatically move away from the point of justice. Conversely, if the judge renders a decision that is closer to justice, then automatically the judge will move away from the point of legal certainty. Meanwhile, the point of benefit itself is between the two. Herein lies the limit of freedom of judges, where the judge can only move between the two dividing points. With a reasoned consideration, a judge will determine when he will be near the point of legal certainty and when he will be near the point of justice. So it is not entirely true that judges in examining a case decide to be free and without limits (Siahaan, 2006;65-66). 
Purwoto S. Gandasubrata, former Chief Justice of the Indonesian Supreme Court (1994), stated that:

"Ideally, the judge's decision must meet 2 (two) requirements, namely theoretical requirements and practical requirements. The theoretical requirement means that it is in accordance with a proven theory. A judge's decision is considered good and correct if it is in accordance with his theory. Practical requirements mean that they are in accordance with the needs of practice in the field, namely being able to achieve the desired goals and can be practiced. A decision is deemed appropriate and correct if it meets practical needs".

It is hoped that a judge's decision in settling a case is expected not only to be seen from the point of view of statutory provisions, but is also expected to consider the sense of justice and benefit (Margono,2019;120).

The case in the Supreme Court Decision Number: 50PK/PDT/2016 in which a foreigner, Namely Mrs. Susi Johnston against an Indonesian citizen namely Tety Carolina and a Notary I Made Pria Dharsana. Land disputes in question in the case in the form of property rights, namely:

1. Property Rights Number 1860 / Village Buduk, covering an area of $665 \mathrm{~m}^{2}$, Measurement Letter dated May 13, 1998, Number 13/1998 obtained on the basis of a sale and purchase with Mr. Andrianto Kariadi based on the Sale and Purchase Deed dated 14-1-2000 with Number 3/2000 which made in the presence of a Notary / PPAT Tutik Danakusuma, SH;

2. Property Rights Number 1861 / Village Buduk, covering an area of $298 \mathrm{~m}^{2}$, Measurement Letter dated May 13, 1998, Number 15/1998 obtained on the basis of a sale and purchase with Mr. Andrianto Kariadi based on the Sale and Purchase Deed dated 14-1-2000 with Number 2/2000 which made at Notary / PPAT Tutik Danakusuma, SH;

3. Property Right Number 1319 / Village Buduk, area of 1,650 $\mathrm{m}^{2}$, Situation Picture dated February 7 , 1996, Number 834/1996 obtained on the basis of a sale and purchase with Mr. Andrianto Kariadi based on the Sale and Purchase Deed dated 14-1-2000 with Number 1/2000 made in Notary / PPAT Tutik Danakusuma, SH.

The three property rights were obtained on the basis of an agreement dated January 24, 2000 with legalization Number 3258L / 2000, by Tutik Danakusuma, S.H., Notary in Denpasar, Bali. The agreement proves that the existence of the name Tety Carolina (PK I Respondent) listed in SHM Number 1860 / Village Buduk, Number 1861 / Village Buduk, and Number 1319 / Village Buduk is only limited to borrowing names, and not as the owner.

In deciding the case, the panel of judges granted the request for reconsideration, namely Mrs. Susi Johnston because the panel of judges considered several things, namely:

1. Whereas the Petitioner for Reconsideration is the legal wife of Bruno Piazza who has borrowed the name of Tety Carolina (Respondent for Reconsideration) to buy three plots of land with title certificates accompanied by an agreement dated January 24, 2000 in the presence of Notary Tutik Danakusuma;

2. Whereas the Respondent for Reconsideration has only borrowed his name so that the three certificates of ownership in the name of the Respondent for Reconsideration are not accompanied by original evidence and the obvious error is that until now there has been no sale and purchase certificate, only a sale and purchase agreement so that there has been no transfer of ownership rights;

3. Whereas the Petitioner for Reconsideration did not attend the trial because the Respondent for Reconsideration had a bad faith because he was suing the Petitioner for Reconsideration by using the wrong address and name listed in the lawsuit. Defendant II is Susi Johnston who lives at Jalan Subak Pangi Number 9, Parerenan Village, Badung Regency, while the name of the Reconsideration Petitioner is Susan Elizabeth Johnston who lives at Jalan Sempol Number 20 Parerenan Mengwi, so that the Reconsideration Petitioner was disadvantaged because he could not defend his rights. his rights in court proceedings; Considering that the Plaintiff's deception existed so that it did not include in the lawsuit the actual name of Defendant II or the actual address of Defendant II in the Plaintiff's claim, while the Plaintiff had known about the name and address because Defendant II held / kept the original title certificate in his name. The Plaintiff has caused the Defendant to lose the opportunity to defend his rights in court proceedings, so the lawsuit is imperfect so that the lawsuit must be declared unacceptable.

4. Whereas based on the above considerations, the Supreme Court is of the opinion that there is sufficient reason to grant the petition for reconsideration from Mrs. SUSI JOHNSTON and cancel the Supreme Court Decision Number 1540 K / PDT / 2014 dated 27 November 2014 and the Supreme Court will try this case again.

From the consideration of the above judge that there is an act and agreement to borrow the name between the Applicant of Review and the Respondent of the Review, where the agreement is done on the basis of trust. That the three areas of property that are the disputed land are the paying land and the actual owner is the husband or heir of the Return Review Er Applicant, Mr. Bruno Piazza, and the Review Respondent borrowed only his 
name. In addition, according to the panel of judges there is no evidence of deed of sale and purchase that there is only a binding agreement on trade so there has been no transfer of property rights.

Book III of the Civil Code regulates several forms of agreement, including the sale and purchase agreement, exchange, lease, storage of goods, lending and borrowing, granting of power, grants and borrowing. Currently in society, various forms of agreements outside the Civil Code have developed or are also called innominaat agreements or anonymous agreements, for example, one of which is a nominee agreement.

Innominaat agreement is an agreement made based on the principle of freedom of contract as referred to in Article 1338 of the Civil Code. However, the innominaat agreement is not specifically regulated in the Civil Code. Even though it is not specifically regulated in the Civil Code, the innominaat agreement must still comply with the regulations contained in Book III of the Civil Code, especially the principles of agreement law contained therein.

Based on the Civil Code, a nominee agreement made by fulfilling all the elements of the validity of the agreement in accordance with the articles in the second chapter of book III of the Civil Code is valid. But on the other hand, it can be said that there is an indication that the nominee agreement is an act of legal smuggling, that is, deviating from the rules contained in the national law, in this case the national land law relating to the prohibition of land ownership by foreign nationals in Indonesia directly or indirectly.

According to the author, the panel of judges did not decide how one part of the disputed land was and in its decision did not state that the disputed land fell to the Respondent for Reconsideration or the land fell to the state as in Article 26 paragraph (2) of the UUPA. In the opinion of Maria S.W. Sumardjono provisions regarding the requirements of the subject of rights, especially against foreign nationals, accompanied by sanctions for violations are contained in Article 26 paragraph (2) of the UUPA. Violation of this provision results in the transfer of property rights to foreign nationals null and void by law and the rights to land belongs to the state.(Sumardjono, 2007;7).

The transfer of land rights directly or indirectly to foreign nationals, the land will belongs to the state. The creation of a nominee agreement is one way of transfering land rights to foreign nationals indirectly. However, the panel of judges decided to overturn the Supreme Court's Decision Number: 1540 K/PT/2014 dated November 27, 2014 and granted the application for review of the Review Applicant.

Furthermore, the panel of judges considers the reasons put forward by the Petitioner for Reconsideration in the memory of the reconsideration, one of which states that there are obstacles to the prevailing laws and regulations in Indonesia, which stipulate that foreign nationals may not have ownership rights to land, so while waiting the application process for a reduction of rights, the sale and purchase of the three land parcels mentioned above which was carried out by borrowing the name Tety Carolina (PK I Respondent), and to guarantee Bruno Piazza's interests, an Agreement dated 24 January 2000 was made between Bruno Piazza and Tety Carolina. (Respondent PK-I) regarding: the name loan agreement, which has been legalized by the same Officer-Notary / PPAT: Tutik Danakusuma, S.H., Notary / PPAT in Denpasar, Bali with legalization Number 3258-L / 2000; (Attached Evidence of Pmh PK-10a and 10b). Furthermore, that with the intention that later it would not be troublesome in the management and / or application for a right to the three land (Right of Use), then an accessory was made in the form of a Sale and Purchase Agreement between Bruno Piazza and Tety Carolina (Respondent PK-I), as stated in the Sale and Purchase Agreement Deed Number 42 and followed by the Power of Attorney Deed Number 43, all dated November 28, 2005, drawn up before I Made Pria Darsana, SH, Notary in Kuta, Denpasar, Bali.

According to the author, the making of the nominee agreement is very clearly carried out for the control of private land by foreign citizens and the Reconsideration Petitioner argues that the making of the sale and purchase agreement deed was carried out so that the Reconsideration Petitioner could reduce the right to use rights because foreign citizens were not allowed to have land with property status.

In relation to the implementation of the judiciary, the panel of judges also has a legal umbrella to carry out its duties and authority in the court, as stated in Article 1 paragraph (1) of Law No. 48 of 2009 concerning the Power of Justice:

"Judicial power is the power of an independent state to administer the judiciary for law enforcement and justice based on Pancasila and the 1945 Constitution of the Republic of Indonesia, for the sake of implementing the State of Law of the Republic of Indonesia".

The existing legal protection does not make the panel of judges act arbitrarily in carrying out their duties, it does not mean that judges can just decide, there are rules that must be observed. Judges should not be pressured by other parties, freedom to interpret laws, freedom to seek legal principles and basis in accordance with the development of society, freedom to follow or not follow jurisprudence and freedom to control laws that are contrary to the interests of society (Hamami, 2013;127).

Freely, a judge is free to decide a matter that is presented to him, and the judge in deciding a case, must have a basis. However, judges in deciding a case, especially in the Supreme Court Decision No. 50PK /PDT / 2016, the judge does not decide a case based on a rule that applies. Judges do not immediately decide cases 
based on mere legal certainty. Sudikno Mertokusumo (2010;207) describes in law enforcement there are usually three elements that must be considered, namely legal certainty (rechtssherheit), benefit (zueckmassigkzit), and justice (gerechtigkeit). Therefore, the judge must also consider in terms of justice and benefits arising from the verdict. However, in judicial practice, it is very difficult for a judge to accommodate these three principles in a single ruling.

Even though a judge is independent in deciding a case, he must pay attention to justice and benefit to the community in general, and for the parties in particular. Mistakes often occur in understanding the meaning of judicial independence (judicial independence), so that the judiciary through judges violates the limits of authority or abuse of authority (abuse of authority) (Harahap, 2016;856).

Justice in a decision is very difficult to find benchmarks for the disputing parties. Justice for one party is not necessarily fair for the other party. Fair basically means putting something in its place and giving to anyone what is their right, which is based on the principle that all people are equal before the law (equality before the law). Justice in the Supreme Court Decision Number: 50PK / PDT / 2016 according to the author is although the name stated in the certificate is the name of the Reconsideration Respondent and the certificate at that time was a Reconsideration Applicant who was a foreign citizen, the judge decided in his decision that the Reconsideration Petitioner was the buyer of 3 (three) parcels of land and the Reconsideration Petitioner was the real owner 3 (three) parcels of land. So those entitled to the 3 (three) parcels of land rights are the Reconsideration Petitioner which is proven by the Nominee Agreement dated January 24, 2000 before Notary Tutik Danakusuma and the Respondent for Reconsideration is only borrowed his name.

According to the author, the panel of judges decided not based on statutory regulations, namely Article 21 paragraph (1) and Article 26 paragraph (2) UUPA, which means that the decision is far from a point of legal certainty. When a judge makes a decision that is closer to the principle of legal certainty, the judge will automatically move away from the point of justice. Conversely, if the judge renders a decision that is closer to justice, then automatically the judge will move away from the point of legal certainty. Meanwhile, the point of benefit itself is between the two. Herein lies the limit of freedom of judges, where the judge can only move between the two dividing points. Emphasis on the principle of legal certainty tends to maintain written legal norms.

So, based on the theory that the author described in the previous chapter, the panel of judges of the Supreme Court in their decision was not based on the principle of legal certainty, because the panel of judges won the Reconsideration Petitioner who was a foreign citizen. The panel of judges should have decided using Article 21 paragraph (1) and Article 26 paragraph (2) of the UUPA, where the transfer of land rights, which is directly or indirectly transferred to foreign nationals, the land falls to the state. This is the consequence of the smuggling of laws in the form of a nominee agreement.

According to the theory of legal certainty used in this research, according to Peter Mahmud Marzuki, legal certainty contains two definitions, namely, first, the existence of general rules makes individuals know what actions are allowed or not to be done, and second, in the form of legal security for individuals from abuse. the government because of these general rules, individuals can know what the state may impose or do on individuals. Legal certainty is not only in the form of articles in the law, but also consistency in the decisions of other judges for similar cases that have been decided.

Furthermore, with regard to the principle of justice, the panel of judges in their decision won the Petitioner for Reconsideration and defeated the Respondent for Reconsideration, which means that the decision is fair for the Petitioner for Reconsideration and unfair for the Respondent for Reconsideration who is an Indonesian citizen. However, if seen from the evidence presented by the Reconsideration Petitioner, the Petitioner for Reconsideration is very entitled to the three land parcels because all costs incurred to buy and build on the three land parcels came from the husband of the Reconsideration Petitioner who is a foreign citizen.

Based on the theory of legal protection, legal protection is obtained in two situations, namely when an agreement is made between the two parties by making clauses that the parties want and agree on (Isnaeni, 2016; 160). Second, legal protection is obtained from regulations made by the competent authorities (Isnaeni, 2016; 163). If reviewed by the decision of the Supreme Court judge, in his consideration it confirms that the Respondent for Reconsideration has only borrowed his name on the title certificate purchased by the Petitioner for Reconsideration, which means that the agreement is what they want. However, if viewed from Article 21 paragraph (1) and Article 26 paragraph (2) UUPA, the Respondent for Reconsideration is not protected, because the disputed land should have fallen to the state or the land fell to the Respondent for Reconsideration because legally the name of the Respondent for Reconsideration written on the property status certificate.

Supreme Judge I Gusti Sumanatha emphasized that the Supreme Court does not recognize nominee agreements in land ownership. This nominee agreement is legal smuggling that must be prevented (Elnizar, Normand Edwin. 2020). Sumanatha also explained that the nominee has the right to transfer, sell, burden, guarantee, and take any action on the object in question in the name of the law. The attitude of the Supreme Court on this matter has been affirmed in the Supreme Court Circular Letter (SEMA) No.7 of 2012 which 
mentions the question of buyers in good faith. So the Supreme Court should win the Respondent's for Reconsideration party which is the nominee in the case.

\section{CONCLUSION}

1. The nominee agreement is clearly in violation of the law, namely the UUPA. UUPA prohibits foreign nationals to own land with property status, it is no longer in accordance with the terms of the validity of an agreement Article 1320 civil code (KUHPerdata) concerning halal causality. In addition, if you look at the sound of Article 1335 and Article 1337 of the Civil Code (KUHPerdata), it is clear that the nominee agreement violates the law and contains false causes, then the agreement has no power.

2. The Supreme Court Judge decided the case related to the nominee agreement in the Supreme Court Decision Number: 50PK / PDT / 2016, which was in favor of the Reconsideration Petitioner who was a foreign citizen. According to the author, the panel of judges must decide based on the applicable regulations, namely UUPA. Foreign nationals are not allowed to own land with the status of property rights in Indonesia, so that foreign nationals carry out legal smuggling by entering into nominee agreements with Indonesian citizens. This is an act that indirectly transfers rights to land to foreign citizens, and the land should belongs to the state as stated in Article 26 paragraph (2) UUPA..

\section{REFERENCES}

\section{Book}

Arba. 2017. Hukum Agraria Indonesia. Jakarta. Sinar Grafika.

Budiono, Herlien. 2010. Hukum Perjanjian dan Penerapannya di bidang Kenotariatan. Bandung. Citra Aditya Bakti.

Hamami, Taufiq. 2013. Peradilan Agama Dalam Reformasi Kekuasaan Kehakiman di Indonesia. Jakarta. Tatanusa.

Harahap, M. Yahya. 2016. Hukum Acara Perdata Tentang Gugatan, Persidangan, Penyitaan, Pembuktian, dan Putusan Pengadilan. Jakarta. Sinar Grafika.

Isnaeni, Moch. 2016. Pengantar Hukum Jaminan Kebendaan. Surabaya. PT. Revka Petra Media.

Khairandy, Ridwan. 2014. Hukum Kontrak Indonesia dalam Perspektif Perbandingan (Bagian Pertama). Yogyakarta. FH UII Press.

2004. Iktikad Baik dalam Kebebasan Berkontrak. Jakarta. Program Pascasarjana Fakultas Hukum Universitas Islam Indonesia.

Margono, A.. 2019. Asas Keadilan, Kemanfaatan Dan Kepastian Hukum Dalam Putusan Hakim. Jakarta. Sinar Grafika.

Mertokusumo, Sudikno dan Pitlo, A. 1993. Bab-Bab Tentang Penemuan Hukum. Jakarta. Citra Aditya Bakti.

Mertokusumo, Sudikno. 2010. Mengenal Hukum Suatu Pengantar. Yogyakarta. Cahaya Atma Pustaka.

Santoso, Urip. 2015. Perolehan Hak Atas Tanah. Jakarta. Ctk. Kesatu Kencana.

Suharnoko. 2015. Hukum Perjanjian Teori dan Analisis Kasus. Jakarta. Ctk. Kesembilan, Kencana.

Suherman, Ade Marman dan Satrio, J. 2010. Penjelasan Hukum tentang Batasan Umur Kecakapan dan Kewenangan Bertindak Berdasar Batasan Umur. Jakarta. National Legal Reform Program.

Sumardjono, Maria SW. 2008. Alternatif Kebijakan Pengaturan Hak Atas Tanah Beserta Bangunan Bagi Warga Negara Asing Dan Badan Hukum Asing. Kompas. Jakarta. . 2007. Kebijakan Pertanahan Antara Regulasi dan Implementasi. Jakarta. Buku Kompas.

\section{Regulations}

Kitab Undang-Undang Hukum Perdata.

Undang-Undang Nomor 5 Tahun 1960 tentang Peraturan Dasar Pokok-Pokok Agraria.

\section{Magazines}

Siahaan, Lintong O. 2006. Peran Hakim Agung Dalam Penemuan Hukum Dan Penciptaan Hukum Pada Era Reformasi Dan Transformasi, Majalah Hukum Varia Peradilan Tahun Ke XXI No. 252 hlm. 65-66. Jakarta. Ikahi. November 2006.

Gandasubrata, Purwoto S. 1994. Bina Yustitia. Mahkamah Agung RI. Jakarta.

\section{Internet}

Elnizar, Normand Edwin. 2020. "Tenang! Pembeli Tanah dari Nominee Tak akan Dirugikan Asalkan..." https://www.hukumonline.com/berita/baca/1t5e535981a7b23/tenang-pembeli-tanah-dari-nominee-takakan-dirugikan-asalkan/ access on 18 May 2021 at 10:56 WITA. 